\title{
妊婦・授乳婦に関する食習慣調查（第 2 報） \\ Eating Habits of Pregnant and Lactating Women in Japan (Part 2)
}

\author{
食品の禁忌理由及び推奨されている食品 \\ Reasons for Food Taboo and Recommended Foods \\ 日本女子大学 (Japan Women's University) \\ 荒 井基 (Moto Arai) 鈴 木 ひろ子 (Hiroko Suzuki) \\ 神奈川県立山北高等学校 (Kanagawa Yamakita High School) \\ 真田成 子 (Shigeko Sanada)
}

Following Part 1, the reasons for placing taboos upon certain foods and, on the other hand recommending foods for pregnant and lactating women were studied. The following results were obtained:

1) Reasons for placing taboos upon certain animal foods, fruits and vegetables appeared to be almost fallacious. However, taboos placed on spices, coffee and alcoholic beverages on the grounds of medical and nutritional knowledge were reasonable.

2) Notwithstanding, the fallacious reasons for taboos, over $40 \%$ of the subjects obeyed the taboos. Nutritional guidance is therefore thought to be necessary.

3) The subjects gave 150 varieties of recommended foods: 49 vegetables and fruits, 67 animal foods and 34 other foods.

4) Nutritious foods such as cow's milk, small fishes and liver were more highly recommended than traditional Japanese foods which has been considered to be nutritious, e.g., carp, miso-soup, and rice cake, etc.

5) Most reasons for recommendation were due to acceptablility. Even if this was so many subjects did not know why those foods are recommendable.

\section{緒 佥}

第 1 報では妊婦・授乳婦に関する食習慣の調査結果として禁忌食品の知悉度, 伝承者, 禁忌食品の出現 頻 度, 地方別出現状沉などについて報告したが, 第 2 報では各食品の禁忌理由ならびに禁忌に対する態度扣よび 推奖されている食品などについて報告する。

\section{調 查 方 法}

調查対象，調査方法，調査時期などすべて第 1 報に記した通りである。

\section{調查結果および考察}

(1) 禁忌理由の検討

表 1，(a)，(b)，(c)，(d)は主な禁忌食品とそれらの禁忌理由ならびに調査対象の禁忌に対する態度を調べた結 果である。禁忌理由を妊娠期，分婏期，授乳期に関するもの拉よび胎児（乳児をふくむ）に関するものとに分 


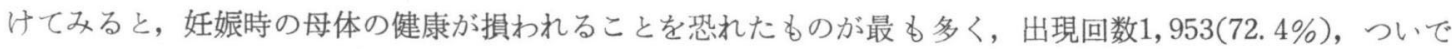
胎児に関するもの 512 回 $(19.0 \%)$ ，授乳期に関するもの171回 $(6.3 \%)$, 分婏時の異常に関するもの63回（2.3 \%)という順であった。

妊娠時の異常に関するものでは流産が最も多く50\%以上を占め，ついで “血を荒す” が $22 \%$, 消化器系の 障害が $8 \%$ であった。胎児に関するものでは，子どもの奇形を恐れた理由が最も多く $30 \%$ 以上であった。分婏 期では難産，産後の快復不良に関するものがほとんどを占め，授乳期では乳汁分泌不良が $85 \%$ 超えていた。 これらの禁忌理由はいずれも妊娠・出産に関して是非とも避けたい事がらではあるが，長野ら ${ }^{3)}$ あ述べている ように，現代医学や栄養学と食品との結ぴつきによって禁忌が成立したと考えられるものがきわめて少い。す なわち動物性食品についてみると，比較的消化がよくないと考えられる“たこ”“するめ”などについては， 禁忌の主な理由は“不消化” ではなく，流産，難産（胎児が胎盘にすいつくなどの理由），血を荒すなどであ る。鬼肉も野鬼病菌の感染を恐れた理由は全くみあたらず，ほとんどが “三つ口の子が生れる”という迷信的 な理由である。卵，獣肉についても同様で，しかも禁忌を守る者が40\%以上にも拈よんでいることは問題であ る。青い魚の“じんましんがでる”生魚の“食中毒を起す”を除けばほとんどが，動物の形状，習性その他か らの連想に基づた不合理な禁忌である。

いか, 獣肉, 卵, たらなと゚日常入手が容易で，比較的安価な良質蛋白質源がこのような不合理な禁忌によっ て妊産婦の摂取を阻んでいることは実害が大きいと考えられる。また限られた地域であるが“はたはた”の禁 忌が全面的に守られていることも問題である。

植物性食品についても全く同様な傾向がみられる。柿，梨，せんいの多い简，わらび，ごぼうなどは消化の 面で一度に多食すべきでないと考えられるが，これらの食品の主な禁忌理由は“冷える”“流産する”“血を荒 す”などである。なすについてもその形や色からの連想に基つくく“子宮が下る”“色の黒い子が生まれる”など があげられているがフィリッピンでも同じ理由（後者）が信じられている。

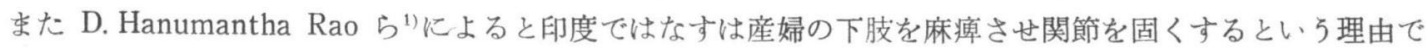
禁じられている。しかしなすは栄湌価の面からみて，これが禁忌されてもそれ程実害は大きいと思われない が，かぼちゃ，そば，みかん，緑野菜などが迷信的な理由で禁忌され，禁忌を守る者が40\%を超えていること は不合理である。授乳婦が緑野菜を摂取すると乳児が緑便を排泄するという禁忌理由は车の報告2)によると韓 国でも信じられている。また R. J. Diego ${ }^{3)}$ はフィリッピンでは緑野菜によって母乳が緑色になるという禁忌 が信じられていると述ぺている。また，かぼちゃ，そば，みかんなど禁忌理由も全く不合理であるが, Diego はフィリッピンでも柑橘類の禁忌理由“母乳を凝固させる”が信じられていることを報告している。

このように動物性食品, 植物性食品に対する禁忌理由が信憑性に乏しいのに対して, 香辛・嗜好性食品に関 する禁忌理由は前二者にみられたような荒唐無稽な迷信的なものは少く，大部分がその刺激性が母体や胎児に 悪影響を扣よぼすことを恐れたものである。従って禁忌を守る者るいっそう高率となっている。すなわち香辛 ・嗜好性食品に対する禁忌は迷信的な慣習とい5よりる，医学的，栄養学的知識に基づくのが多いと考えら れる。その他の食品については, 塩分の多いもの, 冷いものが禁じられていることは合理的であるが, 油うこ いものが子の湿疹と関連があるとしているのは信憑性に乏しい。乳児の脂漏性湿骖の分泌物に脂肪がふくまれ ていることからこのような禁忌理由が成立したのであろう。この他酢の物が不合理な理由で禁忌されているこ とも問題である。

以上総括的にみて食品禁忌の理由には依然として迷信的な不合理なるのが多数残存して拈り，特に魚介，獣 
表 1 主な禁忌理由と能忌に対する態度

\begin{tabular}{|c|c|c|c|c|c|c|}
\hline \multicolumn{3}{|c|}{ 禁忌食品名 } & \multirow{2}{*}{$\begin{array}{l}\text { 出現 } \\
\text { 頻度 } \\
\text { (回) }\end{array}$} & \multicolumn{2}{|c|}{ 禁忌を守る者 } & 主な禁忌理由(出現頻度の高い順) \\
\hline \multicolumn{6}{|c|}{ a) 動物性食品 } & \\
\hline い & & か & 368 & 225 & 61.1 & $\begin{array}{l}\text { (1)流産 (2)血を荒す (3)不消化 (4)冷える } \\
\text { にす難産（胎盤 }\end{array}$ \\
\hline た & & $こ$ & 203 & 122 & 60.0 & $\begin{array}{l}\text { (1)流産 (2)難産(胎盤にすいつく), 不消化 (3)胎盤癒着 } \\
\text { (4)骨のない子子が生まれる }\end{array}$ \\
\hline 香 & & 肉 & 102 & 52 & 50.9 & 三つ口の子が生れる \\
\hline 青 & い & 魚 & 113 & 62 & 54.8 & (1)血を荒す (2)じんましん (3)不消化 (4)流産 \\
\hline す & る & め & 94 & 51 & 54.2 & (1)流産 （2)血を荒す（3)不消化（4)出血 \\
\hline 獣 & & 肉 & 54 & 23 & 42.6 & $\begin{array}{l}\text { (1)奇形児が生まれる (2)四つ足の子が生まれる (3)三つ口 } \\
\text { の子が生まれる (4)血を荒す }\end{array}$ \\
\hline か & & K & 25 & 18 & 72.0 & (1)流産 （2)冷える （3)肌のきたない子が生まれる \\
\hline ま & & 与 & 25 & 13 & 52.0 & (1)血を荒す （2古い傷がでる（3)乳児に湿綧ができる \\
\hline \multirow[t]{2}{*}{ 与 } & じ & $こ$ & 24 & 15 & 62.5 & $\begin{array}{l}\text { (1)胎児に油がかかる (2)出産異常が起る (3)白子が生まれ } \\
\text { る }\end{array}$ \\
\hline & 卵 & & 23 & 14 & 60.9 & $\begin{array}{l}\text { (1)ふたごが生れる(黄味が二つのもの) (2)毛のうすい子が } \\
\text { 生まれる }\end{array}$ \\
\hline た & & 5 & 17 & 11 & 64.7 & (1)冷える 血を荒す （2流産 ～～～～～～ \\
\hline 完 & & び & 16 & 11 & 69.0 & (1)血を荒す (2)出産異常が起る (3)身体に強すぎる \\
\hline 黒 & & 鯛 & 14 & 9 & 64.3 & (1)流産 （2)血を荒す \\
\hline & 貝 & & 12 & 7 & 58.3 & (1)流産 (2)舌の長い子が生まれる (3)胃をこわす \\
\hline 生 & & 魚 & 11 & 7 & 63.6 & 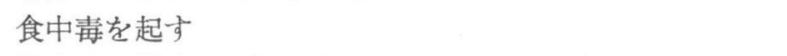 \\
\hline は & たは & た & 10 & 10 & 100.0 & (1)流産 (2)乳汁分泌不良 \\
\hline
\end{tabular}

（b）植物性食品

柿

473

なす

130

67

椎

梨

105

たけのこ 88

69

わ ら び 54

そ ば 41

あ ずき 26

ご涩 522

こんたゃ<21

せ り 20

20
18
茸 111

かぼ

$262 \quad 55.4$

(1)冷兄る (2)流産

(3)血を荒す

(4)乳汁分泌不良 (5)不消 化 (6)出血

51.5 (1)子宮が下る (2)あくが強い, 流産 （3)色の黒い子が生ま れる (4)子どすに湿骖ができる

44.1 (1)血を荒す (2)流産

62

59. 0

(1)泠兄る (2)乳が腐る わく (6)乳児の便がゆるむ

58.0 (1)吹出ものがでる (2)血を荒す (3)流産 (4)あくが強い

(5)湿骖ができる (6)不消化

44.9 (1)血を荒す (2)出血する (3)乳児が黄疽になる (4)乳児に 湿疹ができる (5)乳汁分泌不良

68.5 (1)血を荒す (2)流産 (3)あくが強い (4)脚気になる

61.0 (1)冷える (2)流産 (3)血を荒す

65.4 (1)冷兄る (2)血を荒す (3)出血 (4)流産 (5)乳汁分泌不良

40.9 (1)流産 (2)不消化 (3)色の黒い子が生まれる

57.1 (1)不消化 (2)流産 (3)乳児がひきつける (4)骨のない子が 生まれる

1050.0 (1)血を荒す (2)流産 (3)あくが強い

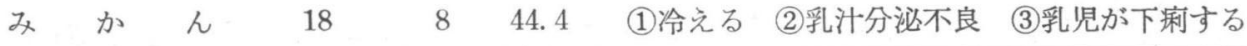




\begin{tabular}{|c|c|c|c|c|c|c|}
\hline \multirow{2}{*}{\multicolumn{3}{|c|}{ 禁忌食品名 }} & \multirow{2}{*}{$\begin{array}{l}\text { 出現 } \\
\text { 頻度 } \\
\text { (回) }\end{array}$} & \multicolumn{2}{|c|}{ 禁忌を守る者 } & \multirow{2}{*}{ 主な禁忌理由(出現頻度の高い順) } \\
\hline & & & & 人数 & $\begin{array}{l}\text { 比率 } \\
(\%)\end{array}$ & \\
\hline \multicolumn{3}{|c|}{ パイナップル } & 18 & 9 & 50.0 & (1)流産 （2)血を荒す \\
\hline ね & & ぎ & 18 & 6 & 33.3 & $\begin{array}{l}\text { (1)血を荒す (2)流産 (3)異常出血 (4)わきがの子が生まれ } \\
\text { る }\end{array}$ \\
\hline 緑 & 野 & 菜 & 16 & 7 & 43.8 & 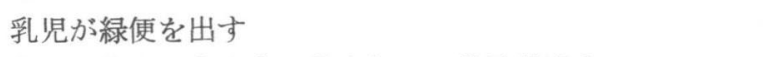 \\
\hline か & & ぶ & 13 & 4 & 30.8 & （1)血を荒す（2)流産（3)冷える（4)異常出血 \\
\hline ふ & & き & 13 & 7 & 53.8 & 1)あくが強い (2)そばかすがでる （3)胎児に悪い \\
\hline \multicolumn{3}{|c|}{ 梅 } & 13 & 2 & 15. 4 & (1)血を荒す （2)産後に悪い（3)出血する \\
\hline と & ろ ろ & 芋 & 11 & 3 & 27.3 & (1)乳汁分泌不良 （2)腹に悪い (3)流産 \\
\hline
\end{tabular}

(c) 香辛・嗜好性食品

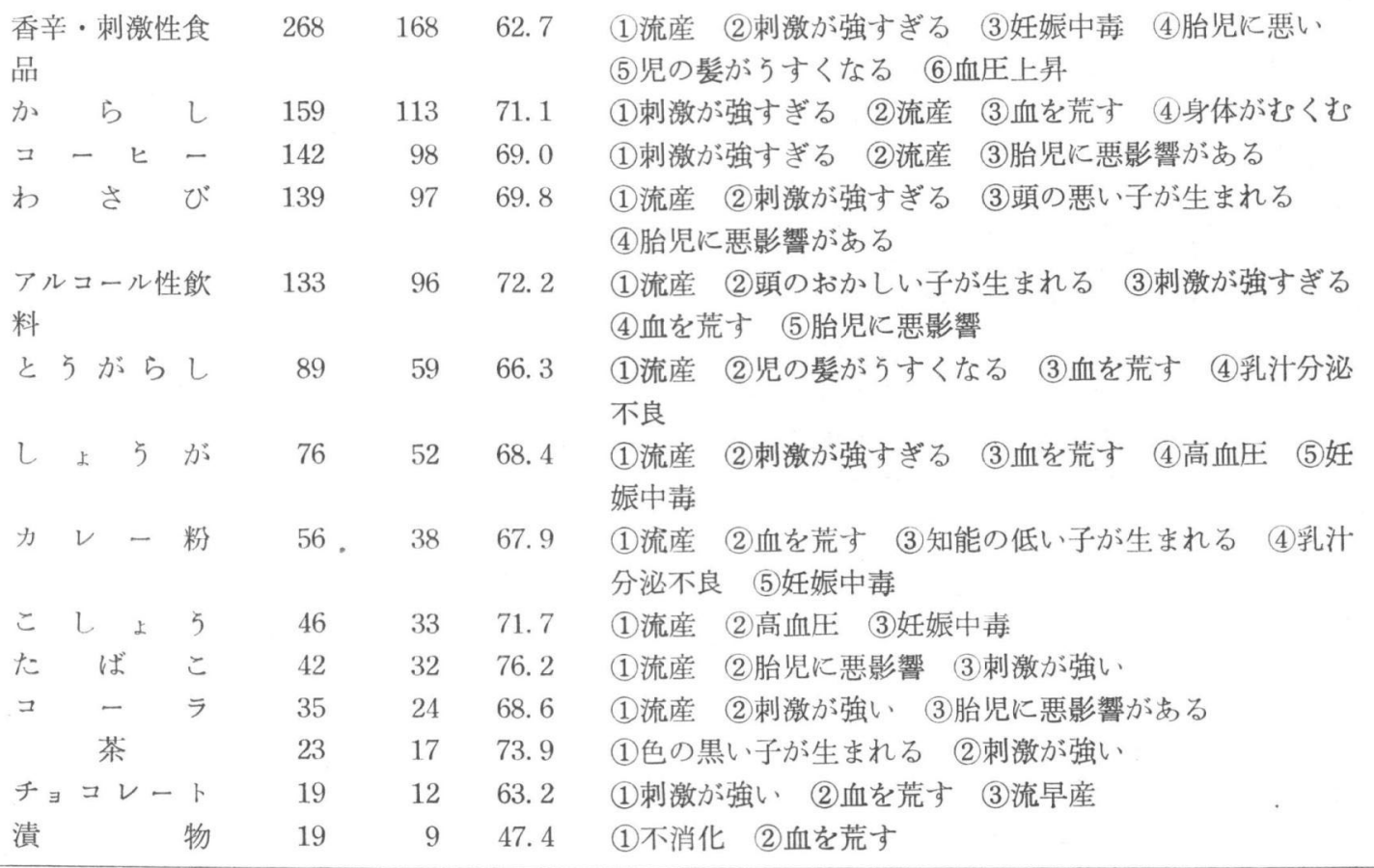

(d) その他

\begin{tabular}{|c|c|c|c|c|}
\hline 塩分の多いも0 & 83 & 57 & 68.7 & (2)腎臓に悪い, 身体がもくむ (3)流産 \\
\hline 冷たいる。 & 65 & 34 & 52.3 & $\begin{array}{l}\text { (1)冷える (2)流産 (3)下㢉, 乳汁分泌不良 (4)難産, 白子 } \\
\text { が生まれる }\end{array}$ \\
\hline 由っこいる。 & 64 & 34 & 53. 1 & $\begin{array}{l}\text { (1)湿疹のある子が生まれる (2)流産, 血を荒す （3)消化不 } \\
\text { 良 (4)胎毒がでる }\end{array}$ \\
\hline の & 46 & 17 & 37.0 & (1)乳汁分泌不良，血を荒す (2)流産 (3)血が下る \\
\hline ま & 29 & 17 & 58.6 & (1)消化不良（2)妊娠中毒３乳が薄くなる \\
\hline W b & 24 & 15 & 62.5 & (1)乳汁分泌不良 (2)流産 \\
\hline
\end{tabular}

註 : ここにまとめたものは単独の食品ではなく(a)(b)(c)に分類できないるのである 
表 2 主な推奨食品

\begin{tabular}{|c|c|c|c|c|c|}
\hline \multicolumn{4}{|c|}{ 食 品 名 } & \multicolumn{2}{|r|}{ 推奨される主な理由（出現頻度の高い順） } \\
\hline 牛 & & & 乳 & 402 & 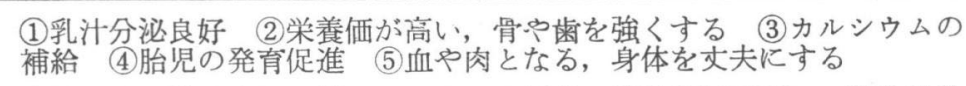 \\
\hline 小 & & & 魚 & 283 & $\begin{array}{l}\text { (1)骨や歯を強くする (2)カルシウムの補給 (3)栄養価が高い (4)乳汁分 } \\
\text { 泌促進 }\end{array}$ \\
\hline み & そ & 6 & 汁 & 281 & 乳汁分泌良好となる \\
\hline \multirow{2}{*}{\multicolumn{2}{|c|}{ 鯉（鯉こ }} & をふく & む) & 233 & (1)乳汁分泌良好となる (2)産後の回復を早める \\
\hline & 餅 & 并 & & 162 & 乳汁分泌良好となる \\
\hline 海 & 藻 & 菒 & 類 & 155 & 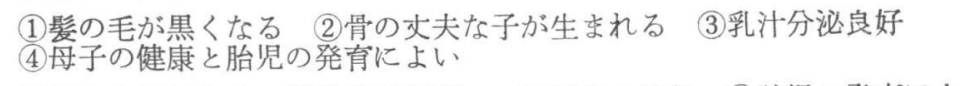 \\
\hline$\nu$ & $\therefore$ & : & - & 144 & (1)増血作用がある (2)栄養価が高い（3)鉄分の補給（4)胎児の発育によ \\
\hline \multirow[t]{2}{*}{ 果 } & 物 & 圽 & 類 & 115 & $\begin{array}{l}\text { (1)ビタミンが含まれている, 乳汁分泌良好となる (2)肌が美しくなる } \\
\text { (3)便秘を防ぐ良質の乳がでる }\end{array}$ \\
\hline & 卵 & 阳 & & 108 & (1)乳汁分泌良好 (2)栄養価が高い（3)増血作用がある，胎児の発育によ \\
\hline 麵 & & & 類 & 102 & 乳汁分泌良好となる \\
\hline 野 & 菜 & 莡 & 類 & 79 & (1)ビタミンがある (2)貧血を防ぐ（3)骨を丈夫にする (4)便秘を防ぐ \\
\hline \multicolumn{4}{|c|}{ 豆豆・あずきをふ類 } & 50 & （1)乳汁分泌良好となる（2)胎児の発育を促進する（3)血や肉となる \\
\hline ほ & 5 れ & $\imath ん$ & 草 & 48 & (1)増血作用がある \\
\hline 甘 & & & 酒 & 48 & 乳汁分泌良好となる \\
\hline 魚 & & & 類 & 48 & (1)乳汁分泌良好（2)血や肉をつくる，骨ごと食べると歯を強くする \\
\hline 肉 & & & 類 & 46 & $\begin{array}{l}\text { (1)栄養価が高い（2増血作用がある (3)乳汁分泌良好となる (4)血や肉 } \\
\text { をつる }\end{array}$ \\
\hline 豆 & 腐・豆 & 製 & 品 & 39 & (1)乳汁分泌良好となる （2)血や肉をつくる· \\
\hline 赤 & & & 飯 & 35 & 乳汁分泌良好となる \\
\hline チ & - & & ズ & 33 & (2)胎児の発育促進 (3)増血作用 \\
\hline s & & & な & 31 & 乳汁分泌良好となる \\
\hline だ & $ん$ & $こ$ & 汁 & 31 & 乳汁分泌良好となる \\
\hline$\check{~ こ}$ & ほ & & 5 & 30 & 乳汁分泌良好となる \\
\hline あ & わ & & $ひ ゙$ & 28 & $\begin{array}{l}\text { (1)目のきれいな子が生まれる (2)乳汁分泌良好となる (3)目の大きい子 } \\
\text { が生まれる }\end{array}$ \\
\hline 汁 & & & 物 & 25 & 乳汁分泌良好となる \\
\hline \multirow[t]{2}{*}{ あ } & め & & 類 & 25 & (1)乳汁分泌良好となる \\
\hline & 鯛 & & & 21 & 乳汁分泌良好となる \\
\hline れ & ん & $こ$ & ん & 21 & 乳汁分泌良好となる \\
\hline 煮 & & & 干 & 19 & $\begin{array}{l}\text { (1)骨や崡が丈夫になる，カルシウムの補給ができる（2)元気な子どすが } \\
\text { 生まれる }\end{array}$ \\
\hline 乳 & 製 & & 品 & 19 & （1)乳汁分泌良好となる（2)栄養価が高い \\
\hline パ & タ & & - & 16 & (1)理由は不明（2)増血作用がある（3)カルシウムの補給ができる \\
\hline ず & い & & き & 15 & (1)乳汁分泌良好となる (2)古血を扔万す (3)扣りすのが早くなくなる \\
\hline に & ん & じ & ん & 15 & (1)乳汁分泌良好となる （2増血作用がある \\
\hline 白 & み & の & 魚 & 13 & 乳汁分泌良好となる \\
\hline パ & パ & 1 & 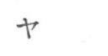 & 12 & 乳汁分泌良好となる \\
\hline ぜ & ん & ま & い & 11 & (1)乳汁分泌良好となる (2)古血を招ろす \\
\hline 米 & の & & 粉 & 10 & 乳汁分泌良好となる \\
\hline
\end{tabular}


肉，卵，野菜，果物においてその傾向が顕著である。しかもそれらの禁忌を守る者がかなりの比率に達してい ることは，今後も栄養指導にあたってとりあげるべき間題と考えられる。

(2) 推奨食品について

妊婦・授乳婦に推奨されている食品は動物性食品 49 種, 植物性食品 67 種, その他の食品 34 種, 合計 150 種で 禁忌食品よりも少なかった。表 2 は主な推奨食品と推奖理由をまとめたものである。

本調査は禁忌食品に関する調査を主体としたので, 推奨食品を信ずるか否か, 実行するか否かなどについて の回答は要求しなかった。

推奨食品には香辛・嗜好性食品はほとんど出現していない。また禁忌食品の中に数えられた食品で, 推奨食 品としてあげられているものもある。動物性食品では魚類, 肉類, 卵などがその主なるのであるが, 禁忌理由 がそれら動物の形状に由来する奇形児の出生を恐れているのに対し，推奨理由は栄養価を認めた結果である。 また推奨食品は授乳婦に関するものが大部分であるため，出産と関りをるつ迷信的なものは少いようである。

個々の推奨食品についてみると十数年前の長野ら ${ }^{4)}$ の報告では, 我が国で古来から伝統的に推奨されてきた 鯉（鯉こくをふくむ）がトップであったのに対し，本調査では牛乳の出現率が最も高く，ついで小魚（骨ごと 食ベられる) があげられ，鯉は 4 位となっている。このことは古来からの言い伝えよりるより栄養知識が普及 した結果ではないかと考察される。

みそ汁, 鯉, 餅, 麵類, 甘酒, 赤飯など层統的な推奨食品の出現頻度るかなり高率ではあるが, 他方海藻 類, レパー，果物類，卵，ほうれん草，チーズ，乳製品などの出現率が高いことも同じ理由によると考えられ る。

表 3 推 奨 理 由

\begin{tabular}{|c|c|c|c|c|}
\hline & 理 由 & $\begin{array}{l}\text { 出現頻度 } \\
\text { (回) }\end{array}$ & $\begin{array}{l}\text { 出現率 } \\
(\%)\end{array}$ & 備 \\
\hline (1) & 乳汁分泌を良好にする & 1520 & 47.3 & \\
\hline$(2)$ & 骨・歯を強くする & 268 & 8.3 & \\
\hline (3) & 増血作用がある・鉄分をふくむ & 173 & 5.4 & \\
\hline (4) & 栄養価が高い、 & 108 & 3.4 & $\begin{array}{l}\text { 漠然と「栄養価」をふくむと答えたものが多か } \\
\text { った }\end{array}$ \\
\hline (5) & 身体の調子をよくする & 73 & 2.3 & \\
\hline (6) & カルシウムを多くふくむ & 59 & 1.8 & \\
\hline (7) & ピタミンを多くふくむ & 37 & 1.2 & V. A, V.C,などと書いたものもこの中にいれた \\
\hline (8) & 理由がよくわからない、 & 825 & 25.7 & 理由について記載のないものもこの項にいれた \\
\hline (9) & その他 & 150 & 4.6 & 雑多の理由の合計 \\
\hline
\end{tabular}

表 3 は推奖理由を大別したものであるが, “乳汁分泌を良好にする”が圧倒的に多く，(2)〜(7)までは栄養学的 知識に基づいた推奖理由と言える。また“理由はよくわからない”というのが，かなり高率で女るのは，理由 については明確に知らないまでも何となく“よい食品”として受け入れてきたことを物語っているようであ る。いずれにしても禁忌理由にみられたような，迷信的，かつ不合理な推奖理由は少ない。ただし，その他の 理由の中には“あわびを食べると目の美しい子が生れる”や“海藻を食べると頭のよい子が生れる”などの迷 信的なものもあったが，その出現頻度は低く全体の $2 \%$ 以下で，長野らの調査の結果の約 $17 \%$ ๖り非常に少く なっていることは注目に値する。すなわち推奖食品では前述したように出産と関りをるったものが少いため信 
性に乏しい不合理なものは時代の推移とともに消隇しつつあるように観察された。

\section{要 約}

（1）禁忌食品に対する禁忌理由は動物性食品，植物性食品に関しては医学や栄着学的知識に基ついて成立し たと考えられるすのは少く，従って信憑性に乏しいものが多かった。

(2) 香辛・嗜好性食品に関する禁忌理由は, 迷信的なものと言5よりも医学や栄着知識と結びついたものが 多かった。

（3）不合理な禁忌理由であるにも関らず，禁忌を守る者が（2，3 の食品を除いて）40\%以上であること は, 今後栄養指導の問題としてとりあげる必要がある。

(4) 推奖食品は動物性食品49種, 植物性食品67種, その他の食品34種, 合計 150 種で禁忌食品よりもその種 類が少なかった。

（5）推奨食品は出現頻度は昔から言い伝えられてきた食品よりも，栄養知識の普及した結果と考えられる牛 乳，小魚，レバーなどに㧍いて高い傾向がみられた。

(6) 推奨理由は禁忌理由にみられたよ5な不合理なるのは少く, 大部分妥当性のあるものとみなされたが, 推奨理由を知らない者も多かった。

$$
\text { 文献 }
$$

1) D. Hanumata Rao \& S. C. Balasubrmanian : Trop. Geogr. Med., 18, 354 (1966)

2) 牟寿美 : 韓国家政学雑誌, 1, 18 (1969)

3) Rizalita J. Diego : Phil. J. Nutr., 17, 307 (1964)

4）長野萊策，長野鈴子，藤井禎子：栄養と食糧，12，426４27（1960）

（受付 : 昭和 49 年 4 月 19 日） 